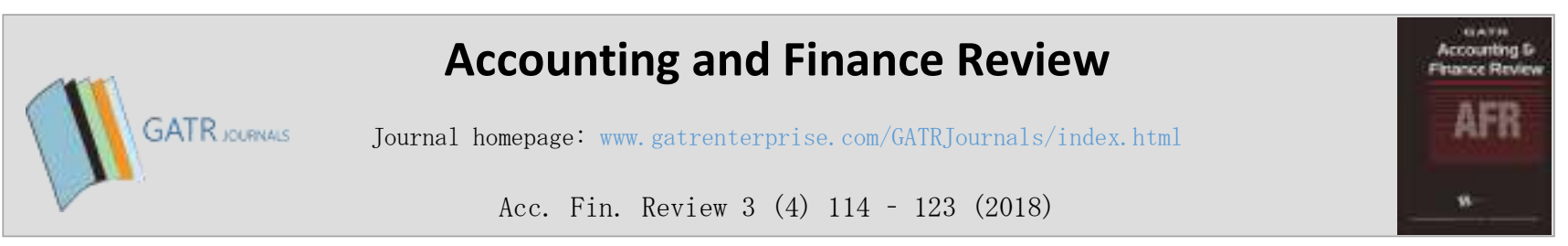

\title{
Information Asymmetry in the Post-IFRS Adoption Period: Evidence from Developing Countries
}

\author{
Juniarti, ${ }^{1}$ * Beatrice Marcellina, ${ }^{2}$ Alvita Angela $^{3}$ \\ 1,2,3 Petra Christian University, Jl. Siwalankerto 121-131, 60236, Surabaya, Indonesia
}

\begin{abstract}
Objective - The adoption of IFRS aims to reduce the level of information asymmetry. Prior studies conducted in developed countries prove that the adoption of IFRS enhances transparency and diminishes information asymmetry. However, in developing countries with a low level of openness, limited regulation, and more centralized ownership, the ability of IFRS to reduce information asymmetry remains unknown. To address this issue, this study aims to investigate whether IFRS adoption will reduce information asymmetry in some developing countries in South East Asia.

Methodology/Technique - This research is applied in three developing countries: Indonesia, the Philippines and Thailand. Information asymmetry is proxied by the cost of capital using the Easton model (2004) and a bid-ask spread. Listed firms from the three countries are selected as the research sample resulting in 5.313 firm-years for the period between 2007 and 2016.

Findings - This study concludes that the adoption of the IFRS decreases information asymmetry in developing countries. These finding confirm that the benefit of the adoption is the same as in developed countries, despite the level of law enforcement in developing countries being lower. Managers, standard authorities and investors must note that the IFRS conveys benefits to the market, which increases transparency by asking lower returns and valuing company stocks appropriately.

Novelty - This study examines the benefits of the adoption of the IFRS in reducing information asymmetry in some emerging countries to enhance the generalization of the results from prior studies that are mostly conducted in developed countries.

Type of Paper: Empirical.
\end{abstract}

Keywords: Bid-Ask Spread; Cost of Capital; Information Asymmetry; IFRS Adoption.

JEL Classification: M41, M48, M49.

\section{Introduction}

Information disclosure plays an important role in the market as it can increase the credibility of a company (Healy and Palepu, 2001). Differences in information cause investors to lose trust in the company, and consequently, ask for higher returns (Ballesteros, et al., 2016).

\footnotetext{
* Paper info: Revised: August 17, 2018

Accepted: December 10, 2018

* Corresponding author: Juniarti

E-mail: yunie@petra.ac.id

Affiliation: Business Accounting, Petra Christian University, Indonesia
} 
The adoption of the IFRS aims to reduce information asymmetry, thereby increasing competition and the efficiency of companies in capital markets and reducing the cost of capital (Covrig, et al., 2007; Daske, et al., 2008; Patro \& Gupta 2014).

The relationship between the IFRS and information asymmetry has been widely studied in developed countries. It is characterized by high protection for investors and strong accounting standards supported by professionals (Leuz et al., 2003; Turki et al., 2017; Daske \& Gebhardt, 2006; Chen et al., 2010). However, research on the relationship between the IFRS and information asymmetry in emerging countries is limited. According to Ball (2006), the implementation of the IFRS is heterogeneous among countries. The effect will be smaller in countries that have fewer differences between local GAAP and the IFRS. The most substantial effect is found in countries with a considerable difference between the local GAAP and the IFRS (Daske et al., 2008).

Furthermore, Indonesia and some other developing countries such as the Philippines and Thailand have identical characteristics; they have weaker and less mature capital markets (Gibson, 2003), limited regulation, and more centralized ownership (Claessens et al., 2000), all of which contribute toward higher information asymmetry.

Mandatory IFRS adoption has proven more effective than voluntary adoption. Turki et al. (2016) states that the adoption of the IFRS reduces information asymmetry. Mandatory IFRS adoption improves the quality of the information more than voluntary adoption (Horton et al., 2012). Several studies have examined the effect of voluntary IFRS adoption on the cost of capital, using an estimation of the implied capital costs for the company. Buijink (2005) examines the adoption of IFRS or non-local GAAP by Europeans Union (EU) companies, however, that study fails to document lower capital costs for IFRS adopters. Daske and Gebhardt (2006) samples German companies with IFRS adoption for the period between 1993 and 2002, identifying higher capital costs associated to the IFRS.

The similarity of characteristics between emerging countries on the one hand and the strength of the mandatory IFRS adoption on the other hand provide an exciting opportunity to examine whether mandatory adoption provides the same benefits for developing countries as for developed countries. By using three developing countries as the research sample (Indonesia, the Philippines, and Thailand), this research aims to contribute to the empirical evidence regarding the power of the mandatory adoption of the IFRS in reducing asymmetric information.

The remainder of this paper is as follows. A review of the literature and the development of hypotheses for this study are presented in the second section. The third section describes the research methods. The fourth section presents and discusses the findings of the study, and the fifth section concludes the paper.

\section{Literature Review}

\subsection{International Financial Accounting Standards}

Changes from rule-based standards to the principle-based standards of the IFRS addresses the need for harmonization of financial information for users worldwide (Christensen et al., 2015). The International Accounting Standards Board (IASB) is an independent group tasked with coordinating national accounting standards to ensure harmonization around the world. Eight IFRS were issued by the IASB in 2006 (Kim and Shi, 2006). The IFRS is the accounting standard issued by the IASB. Changes to international standards are the most significant changes in the context of financial information for more than 100 countries (Sellami \& Slimi, 2006; Daske et al., 2008). Countries in the Asia Pacific began to adopt IFRS in 2005 (Cheong et al., 2010). At present, 166 countries use the IFRS as their financial reporting standard in part or in full.

The IFRS standard demand high quality, transparent, and comparable information in financial statements and help investors in global markets and other users to make economic decisions (Turki et al., 2016). The proponents of the adoption of the IFRS state that it makes disclosure more valuable. Compared to local 
accounting standards in many countries, the IFRS focuses on fair value. Therefore, the IFRS can reduce the flexibility allowed for financial reporting and incorporate the impact of economic events on a company's performance through financial statements in a more precise period (Kim \& Shi, 2006).

\subsection{Local GAAP in Indonesia, the Philippines and Thailand}

Indonesia passed through several stages before deciding to converge with the IFRS. In 1973, based on the published standards of the American Institute of Certified Public Accountants, the Indonesia Accounting Principles Committee issued the Indonesian Accounting Principles (PAI) (Perera \& Baydoun, 2007). In 1994, the committee was changed to the Financial Accounting Standards Committee, and at this point the body comprehensively revised the PAI. The new committee published interpretations of these standards in the Financial Accounting Standards (SAK) on 1 October 1994. In 1998, the Financial Accounting Committee was changed to the Financial Accounting Standards Board (DSAK) with autonomy to formulate and amend the Statement of Financial Accounting Standards (PSAK) and Interpretation of Financial Accounting Standards (ISAK). DSAK uses International Accounting Standards (IAS) as its primary reference in establishing these standards.

Beginning in 2006, Indonesia planned to integrate its standards into the IFRS. Indonesia actively revised most of its accounting standards until they fully converged with the IFRS in 2012. In a domestic setting, Indonesia continues to use local accounting standards, PSAK, despite substantial convergence to the IFRS. The capital market in Indonesia also requires all listed companies to prepare financial statements following the IFRS.

Unlike Indonesia, the adoption of the IFRS in Thailand began on 1 January 2011. Thailand requires all companies listed on the SET to report their financial statements under the IFRS (Intharaprasiti et al., 2016). The adoption of the IFRS, particularly in Thailand, is useful for reducing the manipulation of financial reporting.

Thailand implements local accounting standards known as the Thailand Accounting Standards (TAS). The Federation of Accounting Professions, the board that sets and regulates accounting standards in Thailand, formerly known as the Institute of Certified Accountants and Auditors of Thailand (ICAAT), publishes the TAS as a local accounting standard (FAP). FAP announced the timeline for the adoption of the IFRS in Thailand. In 2011, the top 50 companies were registered on the SET (Klose \& Sabangban, 2011). In 2012, 100 companies listed on the SET began adopting the IFRS. The remaining companies that had not adopted the IFRS did so in 2014. Thailand adopted the IFRS in part; that standard is known as the Thai Financial Report Standards (TFRS). SET also permitted companies that have been listed on the stock market to add or adopt the IFRS, which has not been adopted as the TFRS with additional disclosures.

Before 1996, accounting standards in the Philippines were based primarily on the US GAAP issued by the FASB. However, in 1997, the ASC decided to move to IAS completely. In November 2004, the ASC approved the issuance of the new Philippine Accounting Standards (PAS) and Philippine Financial Reporting Standards (PFRS), directly following the IAS and the IFRS. The Securities and Exchange Commission (SEC) agreed to adopt international accounting standards to enforce high quality and transparent financial reporting and increase credibility and competence in the capital market.

In 2005, the ASC adopted the IFRS issued by the IASB and a revised version of the previously adopted IAS. In 2006, the Financial Reporting Standards Council (FRSC) was established as the successor of the ASC. The FRSC carried out a decision by the ASC to converge Philippine accounting standards with the IFRS standards. It took a while for companies to understand the new accounting standards (Fajardo, 2008). In a domestic setting, the Philippines maintains the use of the IFRS-based local standards, namely, the Philippine Financial Reporting Standards. 


\subsection{Mandatory IFRS Adoption and Cost of Capital}

In economic theory, the high cost of information asymmetry translates to high capital costs, illiquid markets, and suppressed investment activities. IFRS supporters find a basis in the mandated part of the IASB goal, which requires high quality, transparency and comparable information. They argue that the IFRS will encourage the development of capital markets. The IASB has been tireless in promoting IFRS at the political level, and its efforts have paid off in matters ranging from endorsement to mandatory adoption (Ball, 2006).

The mandatory adoption of the IFRS will reduce the cost of equity capital as this standard requires increased financial information disclosure than most local accounting standards (Ashbaugh \& Pincus, 2001). With appropriate implementation and empowerment, the adoption of the IFRS can reduce capital costs by improving the quality and comparability of financial statements. This is supported by the findings of many previous studies that document the increase in disclosure which is believed to reduce the cost of equity (Easly \& O'Hara, 2004; Lambert et al., 2007; Armstrong et al., 2010). Based on this, the following hypothesis is proposed:

H1: Information asymmetry that is proxied by the cost of capital will reduce following the adoption of the IFRS.

\subsection{Mandatory IFRS Adoption and Bid-ask Spread}

Empirical studies on the effect of mandatory IFRS adoption on capital markets are inconclusive. Previous research suggests that the economic consequences of the adoption of the IFRS must increase market liquidity around the time of mandatory IFRS adoption, particularly in countries that have strong law enforcement and managerial incentives for those who disclose transparently. Daske et al. (2008) examine the economic consequences of mandatory IFRS adoption in 26 countries and found that market liquidity increases around the time of the mandatory adoption of the IFRS. The mandatory application of the IFRS in EU countries has increased the accuracy of analysts' estimates and this impact is increasingly evident in countries with strong law enforcement (Christensen, Lee \& Walker, 2009; Byard, Li \& Yu, 2011). Based on this, the following hypothesis is proposed:

$\mathrm{H} 2$ : Information asymmetry that is proxied by the bid-ask spread will be narrower after the adoption of the IFRS.

\section{Research Methodology}

\subsection{Model of Analysis}

The model of analysis to test the two hypotheses of this study is shown below. Control variables that have previously been proven as the determinants of the cost of capital and bid-ask spread are used within the model.

Model 1.1

$\mathrm{CoC}_{i, t}=\beta_{0}+\beta_{1} I F R S_{i, t}+\beta_{2} \operatorname{SIZE}_{i, t}+\beta_{3}$ GROWTH $_{i, t}+\beta_{4} L E V_{i, t}+\beta_{5} C F O_{i, t}+\beta_{6} E P S_{i, t}+\varepsilon_{i, t}$

Model 1.2

$\operatorname{SPREAD}_{i, t}=\gamma_{0}+\gamma_{1}$ IFRS $_{i, t}+\gamma_{2} \operatorname{SIZE}_{i, t}+\gamma_{3}$ GROWTH $_{i, t}+\gamma_{4} \mathrm{LEV}_{i, t}+\gamma_{5} \mathrm{CFO}_{i, t}+\gamma_{6} \mathrm{EPS}_{i, t}+\varepsilon_{i, t}$ 


\subsection{The Operationalization of Variables}

This research measures information asymmetry using two proxies: cost of capital and bid-ask spread. Cost of capital is calculated according to Easton's (2004) model, which uses earnings per share data for the coming year and the following two years. Below is a regression of the cost of capital:

$C O C_{P E G i, t}=\sqrt{\frac{E 0(e p s 2)-E 0(e p s 1)}{P 0}}$

where:

CoCPEG = Cost of capital for companies $\mathrm{i}$ and year $\mathrm{t}$

eps1, eps2 = Earnings per share in year $\mathrm{t}$ and year $\mathrm{t}-1$

$\mathrm{P} 0=$ Share price at the beginning of the year

The second proxy of information asymmetry is bid-ask spread, which is the difference between the bid price and ask price, calculated using the following formula:

Spread $_{i}=\left[\sum_{t=1}^{n} \frac{\text { Ask }_{i t}-\text { Bid }_{i t}}{\left(\text { Ask }_{i t}+B i d_{i t}\right) / 2}\right] / \mathrm{N}$

where:

Spreadi $=$ Average difference between the bid and ask during the stock trading period $\mathrm{i}$

Bidit $=$ The last price offered on the day $\mathrm{t}$ of the stock $\mathrm{i}$

Askit $=$ The last price requested on day $t$ of the stock $\mathrm{i}$

$\mathrm{N} \quad=$ Number of stock trading days in a year

\subsection{Control Variables}

This study includes several control variables in the model of analysis: firm size, growth, leverage, cash flow from operating, and earnings per share. Firm size (SIZE) is measured by the logarithm of the equity market value at the end of the year, following Chae (2005) and Lafond et al. (2007). Sales growth (GROWTH) refers to the annual sales growth rate of a company. Companies with higher growth opportunities are more likely to have higher information asymmetry and bear higher adverse selection costs than companies with low growth opportunities (D'Mello et al., 2008; Krishnaswami \& Subramaniam, 1999; Myers \& Majluf, 1984).

Leverage (LEV) is measured by total debt scaled by the total equity. This indicates the amount of debt borne through the company's capital (Nguyen \& Schubler, 2013; Komala \& Nugroho, 2013; Abasari et al., 2013; Kose, 2011). Cash flow from operating (CFO) is measured by cash flow from operating at the end of the year divided by total assets at the beginning of the year. Earnings per share (EPS) shows the company's net profit that is ready to be distributed to all shareholders. EPS is measured by profit or loss before extraordinary items divided by the weighted average of shares outstanding (Mgbame \& Ikhatua, 2013; Menaje, 2012; Sheetaraman \& Raj, 2011; Perera \& Thrikawala, 2010; Zhu, 2003).

\subsection{Data}

Three countries are selected as the research sample: Indonesia, the Philippines and Thailand. These countries represent emerging countries with similar backgrounds prior to the adoption of the IFRS as the 
mandatory standard. There are 5.313 firm-years for the period between 2007 and 2016. The data for this research is available in Bloomberg, firm websites and the respective stock exchanges.

\section{Results}

\subsection{The Profile of Sample}

Table 1, Panel A presents the profile of the variables of this study. Further, the profiles of each group of adoption, i.e., pre and post-adoption are included. Panel B shows the comparison of the cost of capital and bid-ask spreads in each group.

Table 1. Profile of the Sample

Panel A

\begin{tabular}{|c|c|c|c|c|}
\hline & mean & $\min$ & $\max$ & stddev \\
\hline $\mathrm{CoC}$ & 0,2015 & 0,0000 & 3,0663 & 0,2625 \\
\hline SPREAD & 0,0065 & 0,0000 & 1,1603 & 0,1045 \\
\hline CFO & 0,0763 & 4,6740 & 30,4000 & 0,4989 \\
\hline EPS & 585 & & 465 & 2.830 \\
\hline SIZE & 12,1300 & 9,6666 & 21,6300 & 0,9049 \\
\hline GROWTH & 0,7021 & 3,4680 & 66,1000 & 13,1900 \\
\hline LEV & 1,8020 & $-64,0500$ & 12,5100 & 19,3600 \\
\hline
\end{tabular}

Panel B

\begin{tabular}{|c|c|c|c|c|c|c|}
\hline & \multicolumn{3}{|c|}{ COST OF CAPITAL } & \multicolumn{3}{|c|}{ BID-ASK SPREAD } \\
\hline & PRE & POST & ALL & PRE & POST & ALL \\
\hline Mean & 0,20939 & 0,19087 & 0,20153 & 0,08341 & 0,05259 & 0,06453 \\
\hline Min & 0,00000 & 0,00001 & 0,00000 & 0,00000 & 0,00000 & 0,00000 \\
\hline Max & 2,86700 & 3,06630 & 3,06630 & 0,81444 & 1,16040 & 1,16040 \\
\hline Std dev & 0,25041 & 0,27802 & 0,26252 & 0,12266 & 0,00897 & 0,10545 \\
\hline
\end{tabular}

Table 1, Panel B shows that the mean of the cost of capital is lower post-adoption than pre-adoption. Bidask spreads as another proxy of information asymmetry is narrower post-adoption compared to pre-adoption. The profile of cost of capital and bid-ask spread implies that there is a reduction of information asymmetry post-adoption. Table 2 describes the profile of the sample in each industrial sector.

Table 2. Mean of variables per Industrial Sector

GROWT

$\begin{array}{llllllll}\text { Industrial Sector } & \text { COC } & \text { SPREAD } & \text { CFO } & \text { EPS } & \text { SIZE } & \text { H } & \text { LEV }\end{array}$




\begin{tabular}{|c|c|c|c|c|c|c|c|}
\hline Consumer Goods & 0.21419 & 0.06718 & 0.08145 & 635.8 & 11.96 & 0.2937 & 1.679 \\
\hline $\begin{array}{l}\text { Infrastructure, Utilities, and } \\
\text { Transportation }\end{array}$ & 0.25401 & 0.05444 & $\begin{array}{r}0.00529 \\
6\end{array}$ & 126.4 & 12.15 & 0.7139 & 0.9044 \\
\hline Trade, Service, and Investment & 0.17523 & 0.08172 & 0.07793 & 866 & 12 & 0.7049 & 1.145 \\
\hline Extraction & 0.16601 & 0.02792 & 0.1939 & 439.3 & 12.55 & 3.62 & 6.477 \\
\hline Agriculture & 0.28087 & 0.02955 & 0.09255 & 157.2 & 12.45 & 0.3789 & 2.44 \\
\hline Agro and Food Industry & 0.082019 & 0.06141 & 0.08402 & 423.7 & 12.19 & 0.2464 & 1.963 \\
\hline Finance & 0.23963 & 0.02294 & 0.02625 & 855.9 & 12.36 & 0.1398 & 2.583 \\
\hline Manufacturing & 0.27334 & 0.02640 & 0.09059 & 610.2 & 11.7 & 0.1095 & 1.592 \\
\hline Resources & 0.25575 & 0.00903 & 0.06923 & 794.2 & 12.64 & 0.1852 & 1.609 \\
\hline Technology & 0.28214 & 0.01088 & 0.1226 & 756.9 & 12.32 & 0.08491 & 1.342 \\
\hline
\end{tabular}

\subsection{Hypothesis Testing}

Based on Table 3, the coefficient of PREPOST is negative and significant. This means that there is a significant decrease in the cost of capital following the adoption of the IFRS. SIZE and COUNTRY act as the significant control variables that reduce the level of information asymmetry.

Table 3. Cost of Capital and IFRS Adoption

\begin{tabular}{lccc}
\hline Dependent variable: COC & Coef & p-value & \\
\hline Const & 1,20290 & $0,00010 \quad * * *$ \\
PREPOST & 0,02933 & $0,00720 \quad * * *$ \\
CFO & $-0,00390$ & 0,62860 & \\
EPS & $-0,00000$ & 0,12180 & \\
SIZE & $-0,07436$ & $0,00010 \quad * * *$ \\
GROWTH & $-0,00022$ & 0,50410 & \\
LEV & 0,00009 & 0,93820 & \\
COUNTRY & $-0,04632$ & $0,00010 \quad * * *$ \\
R2 & 0,07283 & & \\
F & 27,52470 & 0,00000 & \\
\hline
\end{tabular}

Consistent with the results of Hypothesis 1, the results of Hypothesis 2 show that PREPOST is also negative and significant in reducing information asymmetry (Table 4). Firm size is also consistent as a determinant of the level of information asymmetry, however, this does not differ among countries.

Table 4. Bid-ask Spreads and IFRS Adoption

\begin{tabular}{llll}
\hline $\begin{array}{l}\text { Dependent variable: } \\
\text { SPREAD }\end{array}$ & Coef & p-value & \\
\hline Const & 0,52181 & 0,00010 & $* * *$
\end{tabular}




\begin{tabular}{lrl} 
PREPOST & 0,02933 & 0,00010 \\
CFO & 0,00390 & 0,72370 \\
EPS & 0,00101 & 0,89080 \\
SIZE & 0,03679 & $0,00010 \quad * * *$ \\
GROWTH & $-0,00009$ & 0,40730 \\
LEV & $-0,00005$ & 0,51250 \\
COUNTRY & 0,00009 & 0,25360 \\
R2 & 0,13401 & \\
$\mathrm{~F}$ & 51,95530 & 0,00000 \\
\hline
\end{tabular}

\section{Discussion}

The results of this study support the argument that mandatory IFRS adoption has the same value in emerging countries as in developed countries. Mandatory IFRS adoption forces managers to comply with the standard. When adoption is mandatory, IFRS demands further and better disclosure and thus is likely to reduce information asymmetry in an imperfectly competitive equity market. This will produce a lowering effect in the cost of equity capital (Armstrong et al., 2010).

These results reinforce the findings of prior studies which state that mandatory IFRS adoption reduces information asymmetry (Turki et al. 2016; Easly \& O'Hara, 2004; Lambert et al., 2007; Armstrong et al., 2010). The quality of information following mandatory IFRS adoption significantly increases (Horton et al., 2012). The proponents of IFRS state that adoption promotes high quality, transparent, and comparable information. This study supports these findings.

The IFRS demands wider disclosure of information compared to those required by previous standards (Ashbaugh \& Pincus, 2001). Thus, the adoption of the IFRS encourages transparency and comparative information and reduces the cost of capital.

IFRS adoption encourages companies to provide broader disclosures that convey internal company information to the outside market. This disclosure increases the availability of information for investors. This leads to a decrease in information asymmetry (Diamond \& Verrecchia, 1991; Lopatta et al., 2015). The availability of further information enables investors to value the company appropriately. Investors who have more information using the provisions of the company will determine the price according to what is requested by others. This causes a gap between bid and ask to be narrower, or the bid-ask spreads to decrease.

\section{Conclusion}

The objective of this study is to determine the effectiveness of mandatory IFRS adoption in reducing the level of information asymmetry. By examining three developing countries, this study confirms that mandatory IFRS adoption significantly reduces the level of information asymmetry. These finding demonstrate the strength of mandatory adoption of IFRS. The results also highlight the superiority of mandatory IFRS because it goes beyond the state aspects so it can be generally accepted.

The results of this study are of concern to the standard authorities. Mandatory adoption maintains the consistency of implementation so the benefit of this approach will be sustainable. This research does not provide sufficient detail about the relevant factors in developing countries such as governance level and investor protections that may potentially influence the benefit of mandatory IFRS adoption. The study also 
fails to make a direct comparison to voluntary adoption. Therefore, future research may explore these issues further.

\section{References}

Absari, Dyatri Utami Arian. Made Sudarma and Grahita Chandrarin. 2013. Analysis of the Effect of Company Fundamental Factors and Systematic Risk on Stock Returns. El-Muhasaba Journal, 3 (2), 1- 29.

Ashbaugh, H. and M, Pincus. (2001). Domestic Accounting Standards, International Accounting Standards, and the Predictability of Earnings. Journal of Accounting Research, 39(3), 417- 434.

Armstrong, C. S., Guay, W. R. and Weber, Joseph P. (2010). The Role of Information and Financial Reporting in Corporate Governance and Debt Contracting. Journal of Accounting and Economics 50(2010), 179-234.

Ballesteros, B. C., I. M. G. Sanchez and J. M. Ferrero. (2016). How are Corporate Disclosures Related to the Cost of Capital? The Fundamental Role of Information Asymmetry. Management Decision, 54(7), 1669-1701. doi: 10.1108/MD-10-2015-0454.

Ball. R. (2006). International Financial Reporting Standards IFRS: Pros and Cons for Investors. Accounting and Business Research 36: 5-27.

Bauman, H., Kaen, F. R., Blease, J. B. R. and Etebari, A. (2010). Employees, Firm Size and Profitability in US Manufacturing Industries. Investment Management and Financial Innovations. 7, 7-23.

Buijink, W. and Cuijpers, Rick (2005). Voluntary Adoption of Non-Local Gap in the European Union: A Study of Determinants and Consequences European Accounting Review, 14(3), 487-524.

Byard, D., Li, Y. and Yu, Y. (2011). The Effect of Mandatory IFRS Adoption on Financial Analysts' Information Environment. Journal of Accounting Research, 49(1), 69-96.

Campos-Espinoza, R., de la Fuente-Mella, H., Silva-Palavecinos, B. and Cademartori-Rosso, D. (2015). Adopting the IFRS and its Impact on Reducing Information Asymmetry in the Chilean Capital Market. NETNOMICS: Economic Research and Electronic Networking, 16(3), 193-204. doi:10.1007/s11066-015-9101-z.

Chae, J. (2005). Trading Volume, Information Asymmetry, and Timing Information. The Journal of Finance, 60(1), 413-442. doi:10.1111/j.1540-6261.2005.00734.x.

Chen, H., Q. Tang, Y. Jiang and Z. Lin. (2010). The Role of International Financial Reporting Standards in Accounting Quality: Evidence from the European Union. Journal of International Financial Management and Accounting, 21(3), 220-278.

Cheong, C. S., S. Kim and R. Zurberuegg (2010). The Impact of IFRS on Financial Analysts' Forecast Accuracy in the Asia- Pacific Region. Pacific Accounting Review, 22(2), 124-146. http://dx.doi.org/10.1108/01140581011074511.

Christensen, H. B., Lee, E. and Walker, M. (2009). Do IFRS Reconciliations Convey Information? The Effect of Debt Contracting. Journal of Accounting Research, 47, 1167-1199.

Christensen, H. B., E. Lee, M. Walker and C. Zheng. (2015). Incentives or Standards: What Determines Accounting Quality Changes Around IFRS Adoption? European Accounting Review, 24(1), 31-61.

Claessens, S., S. Djankov and L. H. P. Lang. (2000). The Separation of Ownership and Control in East Asian Corporations. Journal of Financial Economics, 58,81-112.

Covrig, V. M., M. L. DeFond and M. Hung. (2007). Home Bias, Foreign Mutual Fund Holdings, and the Voluntary Adoption of International Accounting Standards. Journal of Accounting Research, 45(1), 1-70. doi: 10.1111/j.1475679X.2007.00226.x.

D’Mello, R., Krishnaswami, S. and Larkin, P. (2008). Determinants of Corporate Cash Holdings: Evidence From SpinOffs. Journal of Banking \& Finance, 32 (7), 1209-1220.

Daske, H., \& Gebhardt, G. (2006). International financial reporting standards and experts' perceptions of disclosure quality. Abacus, 42(3-4), 461-498.

Daske, H., Hail, L., Leuz, C., \& Verdi, R. (2008). Mandatory IFRS reporting around the world: Early evidence on the economic consequences. Journal of accounting research, 46(5), 1085-1142.

Diamond, D. W., \& Verrecchia, R. E. (1991). Disclosure, liquidity, and the cost of capital. The journal of Finance, 46(4), 1325-1359.

Easton, P. D. (2004). PE ratios, PEG ratios, and estimating the implied expected rate of return on equity capital. The accounting review, 79(1), 73-95.

Easley, D., \& O'hara, M. (2004). Information and the cost of capital. The journal of finance, 59(4), 1553-1583 
Fajardo, Consolacion L. (2008). 8th Global Conference on Business \& Economics. The Evolution of Financial Accounting Standards in the Philippines

Gibson, M. S. (2003). Is corporate governance ineffective in emerging markets?. Journal of financial and quantitative analysis, 38(1), 231-250.

Healy, P. M., \& Palepu, K. G. (2001). Information asymmetry, corporate disclosure, and the capital markets: A review of the empirical disclosure literature. Journal of accounting and economics, 31(1-3), 405-440.

Houqe, N., van Zijl, T., Dunstan, K. L., and Waresul Karim, A. K. M. (2012). The effect of IFRS adoption and investor protection on earnings quality around the world. International Journal of Accounting, 47(3), 333-355.

Horton, J., Serafeim, G., \& Serafeim, I. (2013). Does mandatory IFRS adoption improve the information environment?. Contemporary accounting research, 30(1), 388-423.

Intharaprasiti, C., R. Semakhan, S. Srisukont, C. Love, \& T. Chongsirithitisak. (2016). Earning quality of Accounting information after IFRS adoption: an empirical study of Thai listed firms after IFRS adoption. APHEIT Journal, 5(2), 55-64.

Kim, J. \& Shi, H. (2006). International financial reporting standards, institutional infrastructures and costs of equity capital around the world. Review of Quantitative Finance and Accounting, 42(3), 469-507. doi: 10.1007/s11156-0130350-3.

Klose, M., \& Sabangban, P. (2011). Thailand's convergence to IFRS. Controlling \& Management, 55(1), 25-29.

Komala, Lievila Angela Pinkan. \& Nugroho, Paskah Ika. 2013. "The Effect of Profitability ratio, Liquidity, and Debt towards Investment Return,” Journal of Business and Economics. Vol. 4(11): 1176-1186.

Kose, E. (2011). Dissecting the leverage effect on stock returns. Retrieved May, 2, 2011.

Krishnaswami, S., \& Subramaniam, V. (1999). Information asymmetry, valuation, and the corporate spin-off decision. Journal of Financial economics, 53(1), 73-112.

Lafond, D., Descarreaux, M., Normand, M. C., \& Harrison, D. E. (2007). Chiropractic \& Osteopathy, $15(1), 1$. doi:10.1186/1746-1340-15-1

Lopatta, K., Buchholz, F., \& Kaspereit, T. (2015). Asymmetric information and corporate social responsibility. Business \& Society, 1-31.

Leuz, C., Nanda, D., \& Wysocki, P. D. (2003). Earnings management and investor protection: an international comparison. Journal of financial economics, 69(3), 505-527.

Lambert, R., Leuz, C., \& Verrecchia, R. E. (2007). Accounting information, disclosure, and the cost of capital. Journal of accounting research, 45(2), 385-420.

Menaje, P. M. (2012). Impact of selected financial variables on share price of publicly listed firms in the Philippines. American International Journal of Contemporary Research, 2(9), 98-104.

Mgbame, C.O., \& Ikhatua J.I. (2013). Accounting information and stock price volatility in the Nigerian capital market: a garch analysis approach. International Review of Management and Business Research, 2(1)

Myers, S., \& Majluf, N. (1984). Corporate Financing and Investment Decisions When Firms Have Information That Investors Do Not Have. doi:10.3386/w1396

Nguyen, T., \& Schüßler, A. (2013). Leverage, maturities of debt and stock performance. International Journal of Banking and Finance, 10(1), 5.

Perera, R. A. A. S., \& Thrikawala, S. S.2010. An Empirical Study of the Relevance of Accounting Information on Investor's Decision. ICBI. University of Kelaniya, Sri Lanka

Patro, A. \& Gupta, V. K. (2014). Impact of international financial reporting standards on cost of equity capital for Asian countries. International Journal of Accounting and Financial Reporting, 4(2), 148-170. http://dx.doi.org/10.5296/ijafr.v4i2.6462

Perera, H., \& Baydoun, N. (2007). Convergence with international financial reporting standards: the case of Indonesia. Advances in International Accounting, 20, 201-224.

Seetharaman, A., \& Raj, J. R. (2011). An empirical study on the impact of earnings per share on stock prices of a listed bank in Malaysia. The International Journal of Applied Economics and Finance, 5(2), 114-126.

Sellami, Y. M., \& Slimi, I. (2005). The effect of the mandatory adoption of IAS/IFRS on earnings management: Empirical evidence from South Africa.

Turki, H., Wali, S., \& Boujelbene, Y. (2016). The effect of IFRS mandatory adoption on the information asymmetry. Cogent Business \& Management, 3(1), 1209100.

Turki, H., Wali, S., \& Boujelbene, Y. (2017). IFRS Mandatory Adoption Effect on the Information Asymmetry: Immediate or Delayed?. Australasian Accounting, Business and Finance Journal, 11(1), 55-77. 